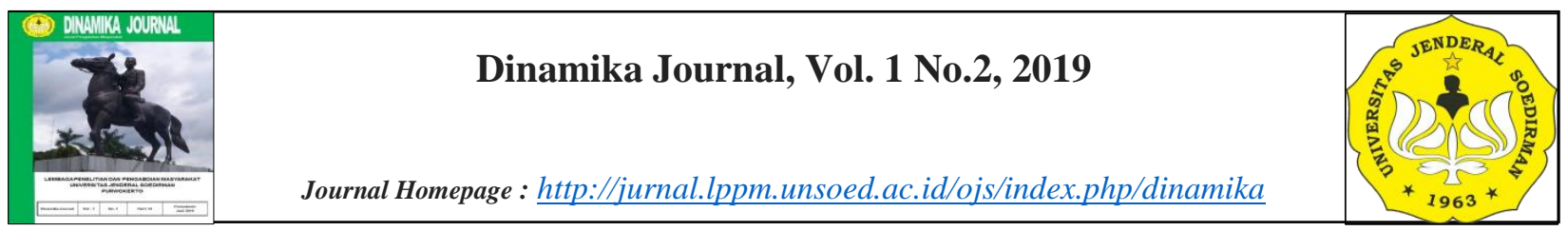

\title{
GAMBARAN GAYA HIDUP PENDERITA HIPERTENSI DI RW 3 KELURAHAN SUMAMPIR KECAMATAN PURWOKERTO UTARA, KABUPATEN BANYUMAS
}

\author{
Ikit Netra Wirakhmi ${ }^{1, *)}$, Dwi Novitasari ${ }^{1{ }^{1}}$ \\ ${ }^{1}$ Fakultas Kesehatan, Universitas Harapan Bangsa Purwokerto \\ *Corresponding author: ikitnetra@yahoo.co.id
}

Received 5 July 2019; Accepted 26 August 2019; Available online 26 August 2019

\begin{abstract}
Abstrak
Hipertensi masih merupakan tantangan besar di Indonesia dan merupakan masalah kesehatan dengan prevalensi yang tinggi. Berdasarkan data dari Puskesmas 2 Purwokerto Utara, penderita hipertensi di RW 3 Kelurahan Sumampir, Kecamatan Purwokerto Utara, Kabupaten Banyumas cukup banyak. Penatalaksanaan hipertensi dapat dilakukan dengan menggunakan obat-obatan ataupun dengan cara modifikasi gaya hidup. Tujuan yang diharapkan dari pengabdian masyarakat ini adalah tersedianya kelompok mandiri penderita hipertensi, tersedianya tensimeter digital, timbangan digital dan dapat mengoperasikan dengan baik, menggambarkan aktivitas fisik, pola makan, kebiasaan istirahat dan kebiasaan merokok penderita hipertensi. Metode pengabdian dilakukan melalui pendidikan kesehatan (ceramah dan diskusi). Berdasarkan hasil pengabdian kepada masyarakat di RW 3 Kelurahan Sumampir, Kecamatan Purwokerto Utara, Kabupaten Banyumas dapat disimpulkan bahwa kegiatan pengabdian kepada masyarakat ini dapat meningkatkan ketrampilan penderita hipertensi terhadap pengoperasian alat tensimeter digital dan timbangan digital, mendapatkan gambaran aktifitas fisik, pola makan, kebiasaan istirahat dan kebiasaan merokok penderita hipertensi.
\end{abstract}

Kat-kata kunci : Hipertensi, gaya hidup

\begin{abstract}
Hypertension is still a big challenge in Indonesia and is a health problem with a high prevalence. Based on data from Puskesmas 2 Purwokerto Utara, hypertension sufferers in RW 3 Sumampir Village, Purwokerto Utara District, Banyumas Regency are quite a lot. Management of hypertension can be done using drugs or by way of lifestyle modification. The expected goals of community service are the availability of independent groups of people with hypertension, the availability of digital tensimeters, digital scales and can operate well, describing physical activity, eating patterns, resting habits and smoking habits of hypertensive patients. The service method is done through health education (lectures and discussions). Based on the results of community service in $R W 3$ Sumampir Village, Purwokerto Utara District, Banyumas Regency it can be concluded that community service activities can increase the skills of hypertension sufferers on the operation of digital
\end{abstract}


tensimeter devices and digital scales, get an overview of physical activity, eating patterns, resting habits and smoking habits of hypertensive sufferers

Keywords: Hypertension, Lifestyle

\section{PENDAHULUAN}

Diagnosis hipertensi ditegakkan bila tekanan darah sistolik $\geq 140 \mathrm{mmHg}$ dan/atau tekanan darah sistolik $\geq 90 \mathrm{mmHg}$ (Perhimpunan Dokter Hipertensi Indonesia, 2019). Sampai saat ini, hipertensi masih merupakan tantangan besar di Indonesia dan merupakan masalah kesehatan dengan prevalensi yang tinggi, yaitu sebanyak $25.8 \%$, sesuai dengan data Riskesdas 2013. Menurut NHLBI (National Heart, Lung, and Blood Institute), 1 dari 3 pasien menderita hipertensi (Muhadi, 2016). Widiyani (2013) menyatakan bahwa Badan Kesehatan Dunia (WHO) menyebutkan jumlah penderita hipertensi akan terus meningkat seiring dengan jumlah penduduk yang bertambah pada 2025 mendatang diperkirakan sekitar 29\% warga dunia terkena hipertensi. Menjalani pola hidup sehat telah banyak terbukti dapat menurunkan tekanan darah, dan secara umum sangat menguntungkan dalam menurunkan risiko permasalahan kardiovaskular. Beberapa pola hidup sehat yang dianjurkan oleh banyak guidelines antara lain adalah olah raga secara teratur (Perhimpunan Dokter Spesialis Kardiovaskular Indonesia, 2015).

Penatalaksanaan hipertensi dapat dilakukan dengan menggunakan obat-obatan ataupun dengan cara modifikasi gaya hidup. Modifikasi gaya hidup dapat dilakukan dengan membatasi asupan garam tidak lebih dari 1/4 - 1/2 sendok teh (6 gram/hari), menurunkan berat badan, menghindari minuman berkafein, rokok, dan minuman beralkohol. Olah raga juga dianjurkan bagi penderita hipertensi, dapat berupa jalan, lari, jogging, bersepeda selama 20 - 25 menit dengan frekuensi 3 - 5x per minggu. Penting juga untuk cukup istirahat (6 - 8 jam) dan mengendalikan stress. Sedangkan untuk pemilihan serta penggunaan obat-obatan hipertensi disarankan untuk berkonsultasi dengan dokter keluarga (Infodatin, 2014).

Berdasarkan data Prolanis (Program Pengelolaan Penyakit Kronis) Puskesmas Purwokerto Utara 2 pada bulan Februari 2018 tercatat 200 pasien dan penderita hipertensi di RW 3 Kelurahan Sumampir cukup banyak. Selain itu, diperlukan gambaran mengenai gaya hidup penderita hipertensi di wilayah RW 3 Kelurahan Sumampir, Kecamatan Purwokerto Utara Kabupaten Banyumas agar dapat dilakukan penatalaksnaan hipertensi lebih lanjut. Setelah kegiatan pengabdian masyarakat ini dilaksanakan, maka tujuan yang diharapkan adalah tersedianya kelompok mandiri penderita hipertensi, tersedianya tensimeter digital, timbangan digital dan dapat mengoperasikan dengan baik, menggambarkan aktivitas fisik, pola makan, kebiasaan istirahatan dan kebiasaan merokok penderita hipertensi.

\section{METODE PELAKSANAAN}

Berdasarkan analisis masalah di atas, maka metode pelaksanaan kegiatan pengabdian dirinci sebagai berikut :

a) Persiapan dan Koordinasi

Tahap persiapan dan koordinasi dilakukan pada bulan Mei 2019. Tahap ini dilakukan dengan metode survey lapangan, pengurusan perizinan dan membagikan undangan ke pasien hipertensi. Pengurusan perijinan dilakukan melalui beberapa instansi terkait sesuai dengan peraturan yang ada di wilayah Kabupaten Banyumas. Koordinasi pelaksanaan pengabdian masyarakat dilakukan pada minggu ke 2 di bulan Mei 2019. 
Koordinasi ini dilakukan untuk memberikan gambaran pelaksanaan pengabdian masyarakat, mendapatkan dukungan dan support serta membantu mengatasi kemungkinan faktor kendala yang mungkin muncul.

b) Pelaksanaan Kegiatan

1) Pembentukan kelompok hipertensi mandiri

2) Pemberian hibah tensimeter digital, timbangan digital dan kartu pemantauan tekanan darah

3) Pemberian materi (ceramah) dan diskusi tentang hipertensi dan manajemennya serta pembagian quesioner

\section{HASIL DAN PEMBAHASAN}

a. Pembentukan kelompok hipertensi mandiri Tim pengabdi menunjuk salah satu orang sebagai ketua.

b. Pemberian hibah tensimeter digital dan kartu pemantauan tekanan darah.

Tim pengabdi memberikan hibah berupa tensimeter digital, timbangan digital dan kartu pemantauan tekanan darah dan melatih cara pengoperasiannya.

c. Pemberian materi (ceramah) dan diskusi tentang hipertensi dan manajemennya serta pembagian questioner mengenai gaya hidup penderita hipertensi

Berikut hasil dari kuesiner yang diisi oleh responden :

Tabel 1. Gambaran Aktivitas Fisik Penderita Hipertensi

\begin{tabular}{|c|c|c|c|c|c|}
\hline \multirow[t]{2}{*}{ Pertanyaan } & \multicolumn{4}{|c|}{ Jawaban } & \multirow{2}{*}{$\begin{array}{c}\text { Jumlah } \\
\text { total }\end{array}$} \\
\hline & $\mathrm{Ya}$ & $\%$ & Tidak & $\%$ & \\
\hline Melakukan olahraga setiap hari & 17 & 65.3 & 9 & 34.7 & 26 \\
\hline Melakukan olahraga $\geq 30$ menit sehari & 12 & 46.1 & 14 & 53.9 & 26 \\
\hline $\begin{array}{l}\text { Melakukan kegiatan sehari/aktivitas sehari- hari } \geq 30 \\
\text { menit }\end{array}$ & 19 & 73 & 7 & 27 & 26 \\
\hline
\end{tabular}

Berdasarkan tabel 1, penderita hipertensi yang melakukan olahraga setiap hari sebanyak $65.3 \%$, namun yang melakukan olahraga $\geq 30$ menit sehari sebanyak $46.1 \%$ dan yang melakukan kegiatan sehari/aktivitas sehari- hari $\geq 30$ menit sebanyak $73 \%$.

Tabel 2. Gambaran Pola Makan Penderita Hipertensi

\begin{tabular}{|l|c|c|c|c|c|}
\hline \multicolumn{1}{|c|}{ Pertanyaan } & \multicolumn{4}{c|}{ Jawaban } & Jumlah \\
\cline { 2 - 6 } & Ya & $\%$ & Tidak & $\%$ & total \\
\hline Makan daging seminggu <3x & 18 & 69.2 & 8 & 30.8 & 26 \\
\hline Makan berlemak tinggi seminggu <3x & 15 & 57.6 & 11 & 42.4 & 26 \\
\hline Makan makanan gorengan seminggu < 3x & 19 & 73 & 7 & 27 & 26 \\
\hline Makan makanan cepat saji seminggu < 3x & 13 & 50 & 13 & 50 & 26 \\
\hline Mengkonsumsi minuman yang berkafein & 16 & 61.5 & 10 & 38.5 & 26 \\
\hline Makan makanan yang diasinkan & 16 & 61.5 & 10 & 38.5 & 26 \\
\hline Makan sayuran seminggu $\geq 3 \mathrm{x}$ & 24 & 92.3 & 2 & 7.7 & 26 \\
\hline Makan buah - buahan seminggu $\geq 3 \mathrm{x}$ & 25 & 96.1 & 1 & 3.9 & 26 \\
\hline
\end{tabular}


Berdasarkan tabel 2, penderita hipertensi yang makan daging seminggu $<3 \mathrm{x}$ sebanyak $69.2 \%$, makan berlemak tinggi seminggu $<3 x$ sebanyak $57.6 \%$, makan makanan gorengan seminggu $<3 x$ sebanyak 73\%, makan makanan cepat saji seminggu $<3 x$ sebanyak $50 \%$, mengkonsumsi minuman yang berkafein dan makan makanan yang diasinkan sebanyak $61.5 \%$, makan sayuran seminggu $\geq 3 \mathrm{x}$ sebanyak $92.3 \%$ dan makan buah - buahan seminggu $\geq 3 \mathrm{x}$ sebanyak $96.1 \%$.

Tabel 3. Gambaran Kebiasaan Istirahat Penderita Hipertensi

\begin{tabular}{|c|c|c|c|c|c|}
\hline \multirow[t]{2}{*}{ Pertanyaan } & \multicolumn{4}{|c|}{ Jawaban } & \multirow{2}{*}{$\begin{array}{c}\text { Jumlah } \\
\text { total }\end{array}$} \\
\hline & $\mathrm{Ya}$ & $\%$ & Tidak & $\%$ & \\
\hline Terbangun $<2 \mathrm{x}$ pada waktu tidur malam & 21 & 80.7 & 5 & 19.3 & 26 \\
\hline Susah tidur $<2 \mathrm{x}$ dalam seminggu & 14 & 53.8 & 12 & 46.2 & 26 \\
\hline $\begin{array}{l}\text { Istirahat/tidur siang }(1-2 \text { jam sehari }) \geq 3 \mathrm{x} \text { dalam } \\
\text { seminggu }\end{array}$ & 13 & 50 & 13 & 50 & 26 \\
\hline $\begin{array}{l}\text { Tidur teratur dalam seminggu (6-8 jam pada malam } \\
\text { hari) }\end{array}$ & 20 & 76.9 & 6 & 23.1 & 26 \\
\hline
\end{tabular}

Berdasarkan tabel 3 penderita hipertensi yang terbangun $<2 \mathrm{x}$ pada waktu tidur malam sebanyak $80.7 \%$, susah tidur $<2 \mathrm{x}$ dalam seminggu sebanyakk $53.8 \%$, istirahat/tidur siang (12 jam sehari) $\geq 3 \mathrm{x}$ dalam seminggu sebanyak $50 \%$ dan tidur teratur dalam seminggu (6-8 jam pada malam hari) sebanyak $76.9 \%$. Berdasarkan tabel 4 penderita hipertensi yang merokok sebesar $7.7 \%$.

Tabel 4. Gambaran Kebiasaan Merokok Penderita Hipertensi

\begin{tabular}{|c|c|c|c|c|c|}
\hline \multirow[t]{2}{*}{ Pertanyaan } & \multicolumn{4}{|c|}{ Jawaban } & \multirow{2}{*}{$\begin{array}{c}\text { Jumlah } \\
\text { total }\end{array}$} \\
\hline & $\mathrm{Ya}$ & $\%$ & Tidak & $\%$ & \\
\hline Merokok & 2 & 7.7 & 24 & 92.3 & 26 \\
\hline Mengisap rokok > 20 batang dalam sehari & 0 & 0 & 26 & 100 & 26 \\
\hline
\end{tabular}

Berdasarkan hasil kuesioner di atas dapat disimpulkan bahwa gambaran gaya hidup yang meliputi aktivitas fisik, pola makan, kebiasaan istirahat dan kebiasaan meroko penderita hipertensi di wilayah tersebut masih belum sesuai dengan modifikasi gaya hidup sebagai bentuk penatalaksanaan hipertensi. Pola hidup sehat dapat mencegah ataupun memperlambat awitan hipertensi dan dapat mengurangi risiko kardiovaskular. Pola hidup sehat telah terbukti menurunkan tekanan darah yaitu pembatasan konsumsi garam dan alkohol, peningkatan konsumsi sayuran dan buah, penurunan berat badan dan menjaga berat badan ideal, aktivitas fisik teratur, serta menghindari rokok. Konsumsi garam berlebih terbukti meningkatkan tekanan darah dan meningkatkan prevalensi hipertensi. Rekomendasi penggunaan natrium (Na) sebaiknya tidak lebih dari 2 gram/hari (setara dengan 5-6 gram $\mathrm{NaCl}$ perhari atau 1 sendok teh garam dapur). Pasien hipertensi disarankan untuk konsumsi makanan seimbang yang mengandung sayuran, kacang-kacangan, buah-buahan segar, produk susu rendah lemak, gandum, ikan, dan asam lemak tak jenuh (terutama minyak zaitun), serta membatasi asupan daging merah dan asam lemak jenuh. Olahraga teratur dengan intensitas dan durasi ringan memiliki efek penurunan tekanan darah lebih kecil dibandingkan dengan latihan intensitas sedang atau tinggi, sehingga pasien hipertensi disarankan untuk berolahraga setidaknya 30 menit latihan aerobik dinamik berintensitas sedang (seperti: berjalan, joging, bersepeda, atau berenang) 5-7 hari per minggu. Merokok merupakan faktor risiko vaskular dan kanker, sehingga penderita hipertensi yang merokok harus diedukasi untuk berhenti merokok (Perhimpunan Dokter Hipertensi Indonesia, 2019). 


\section{KESIMPULAN}

Berdasarkan hasil pengabdian kepada masyarakat di RW 3 Kelurahan Sumampir, Kecamatan Purwokerto Utara, Kabupaten Banyumas dapat disimpulkan bahwa kegiatan pengabdian kepada masyarakat ini dapat meningkatkan kemampuan penderita hipertensi terhadap pengoperasian alat tensimeter digital dan timbangan digital dan menggambarkan gaya hidup penderita hipertensi. Kegiatan selanjutnya diharapkan dapat memberikan terapi komplementer/pendukung sebagai bentuk aktifitas fisik dan dapat melakukan upaya pengontrolan pola makan, kebiasaan istirahat dan kebiasaan merokok pada penderita hipertensi di wilayah tersebut.

\section{UCAPAN TERIMA KASIH}

Tim Pengabdi mengucapkan terima kasih kepada Universitas Harapan Bangsa Purwokerto sehingga kegiatan pengabdian masyarakat ini dapat dilaksanakan.

\section{REFERENSI}

Erwanto, R. dkk. 2017. Lansia dan Keperawatan Keluarga. Nuha Medika: Yogyakarta.

Muhadi. 2016. JNC 8 : Evidence - based Guidiline Penanganan Pasien Hipertensi Dewasa. CDK-236/ vol. 43 no. 1 Tahun 2016. Divisi Kardiologi, Departemen Ilmu Penyakit Dalam Fakultas Kedokteran Universitas Indonesia/RS Cipto Mangunkusumo Jakarta, Indonesia

Muttaqin, A. 2014. Buku Ajar Asuhan Keperawatan Klien Dengan Gangguan Sistem Kardiovaskuler Dan Hematologi. Salemba Medika: Jakarta

Perhimpunan Dokter Spesialis Kardiovaskular Indonesia. 2015. Pedoman Tatalaksana Hipertensi Pada Penyakit Kardiovaskular.

Perhimpunan Dokter Hipertensi Indonesia. 2019. Konsesus Penatalaksanaan Hipertensi 2019. Jakarta

Pusat Data dan Informasi Kementerian Kesehatan (Infodatin). 2014. Hipertensi. Kementerian Kesehatan RI : Jakarta

Riset Kesehatan Dasar. 2013. Balai Penelitian dan Pengembangan Kesehatan. Kementerian Kesehatan RI: Jakarta 